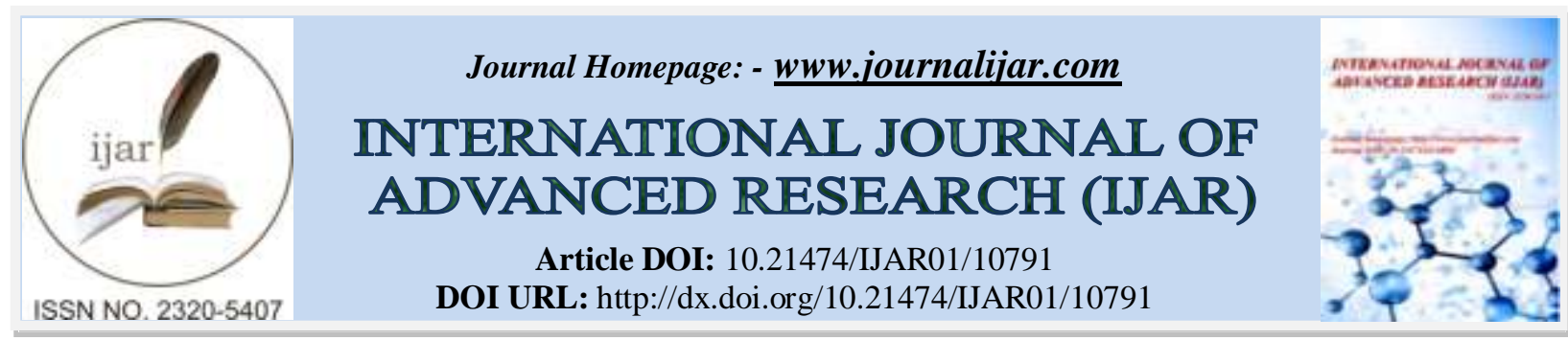

RESEARCH ARTICLE

\title{
EFFECTIVENESS OF TRADITIONAL EXTENSION MODELS AMONG RURAL DWELLERS IN SUB- SAHARAN AFRICAN COMMUNITIES
}

\section{Sennuga Samson Olayemi ${ }^{1}$ and Fadiji Taiye Oduntan ${ }^{2}$}

1. School of Agriculture Food and Environment, Royal Agricultural University, Stroud Road, Cirencester, Gloucestershire, United Kingdom, GL7 6JS.

2. Department of Agricultural Extension and Rural Sociology, Faculty of Agriculture, University of Abuja, FCT, P.M.B. 117, Abuja, Nigeria.

\section{Manuscript Info}

Manuscript History

Received: 10 February 2020

Final Accepted: 12 March 2020

Published: April 2020

Key words:-

Extension Model, Rural Dwellers,

Extension Workers, Communities
Abstract

This article examines the factors influencing the effectiveness of traditional extension models among rural dwellers in Sub-Saharan African communities. The study was conducted in two rural communities in Kaduna State, Nigeria. The representative sample involved 200 randomly selected smallholder farmers. In addition, 20 extension workers were purposively selected from four institutions that provide extension and advisory services in Nigeria. The study used focus group discussions, in-depth interviews and structured questionnaires to collect relevant information. Data were analyzed using statistical software. The overall findings revealed that the current extension services in the study area are ineffective and inefficient to meet the needs of rural farmers. In the same vein, almost all the extension worker participants unanimously reported that after the withdrawal of World Bank funding to Agricultural Development Project (ADP), the Federal Government of Nigeria finds it extremely difficult to independently fund the extension and advisory services. Moreover, $69.5 \%$ of the smallholder farmers indicated that they had no visit/contact with extension agents in the last one year, while $86 \%$ reported that extension service delivery was not effective in the area. Also, exceptionally low numbers of extension workers and poor funding were ranked as the fundamental challenges confronting extension services in the area. Base on this, it is recommended that Federal and State Ministry of Agriculture should recruit more agricultural graduates' youths and train them. More extension workers need to be hired in order to significantly reduce the problem of the extension workers to farm families' ratio which is currently 1:3000 in the Kaduna State, Nigeria.

Copy Right, IJAR, 2020,. All rights reserved.

Corresponding Author:- Sennuga, S.O.

Address:- School of Agriculture Food and Environment, Royal Agricultural University, Stroud Road, Cirencester, Gloucestershire, United Kingdom, GL7 6JS. 


\section{Introduction:-}

Smallholder farmers within Sub Saharan Africa (SSA) face a number of challenges both in terms of production and in marketing their surplus produce. Generally, the focus of agricultural policies are to guide farmers to optimize production without damaging the natural resources they depend on and secondly to assist farmers to access markets (Sennuga, 2019). In many developing countries the local face of these policies is the agricultural extension field officer; however, many of these field officers also face challenges in delivering extension messages to increasing numbers of smallholders. Therefore, it could be argued that both farmers and extension officers face a common challenge of developing effective strategies for information exchange and communication.

Agricultural production in Nigeria has been largely dependent on the concerted efforts of small-scale farmers who are mainly in the rural areas. Ogungbile and Olukosi (2001) outlined the common characteristics of resource-poor farmers which include; stark poverty, illiteracy, malnourishment, financial inadequacies and low rates of return on their small investments. In order to address some of the challenges faced by stakeholders, a number of policies and extension strategies have been implemented; one of these was the World Bank assisted Agricultural Development Projects (ADP) that were introduced into Nigeria in 1975 including the component of the Training and Visit (T\&V) extension system which was initially enthusiastically adopted in many states (Idachaba 2007, Sennuga, 2019). The popularity of the $\mathrm{T} \& \mathrm{~V}$ system was perhaps due to its ability to promote and encourage professionalism, a welldefined structural and institutional arrangement, an inbuilt monitoring and evaluation system and for its flexibility in terms of accommodating other agricultural and rural development projects (Ilevbaoje 2008; Akintonde et al. 2012). However, this model of extension has subsequently been criticized on several counts including: being inefficient and ineffective, a rigid top-down and top-heavy process with too much focus on yield increases, a lack of attention to economics and marketing and not addressing the diverse service needs of smallholders (Ejembi et al. 2006; Anderson et al. 2006; Musa et al. 2013). Indeed, the model is often referred to as "train and vanish" as there was no reinforcing of messages, mentoring or relationship building (Anderson et al. 2006) and no post extension monitoring. In Nigeria, for instance, the Government extension worker to farmer ratio is very high, estimated at 1:3000 against a target of 1: 500 (Arokoyo 2005, Sennuga, 2019). This gap is extremely large to effectively reach out to the creasing needs of the rural communities and this is making direct communication difficult. However, the ICT concept infiltrates perfectly well for its reachability to complement the efforts by improving capacity to connect without costly visits. The ineffectiveness and inefficiency of $T \& V$ approach linked with the traditional extension models for subsistence have led agricultural extension scholars to advocate the application of ICT as a complementary tool in maintaining farmer contact (Anderson et al. 2006; Davis 2008; Aker 2011).

A second challenge facing smallholders centers around inadequate market access, lack of market information, collusion among middlemen, and lack of transportation facilities (Kavoi et al. 2014, Yegbemy et al. 2016). Indeed, millions of smallholder farmers in SSA face incredible challenges in marketing their farm produce while the concerted efforts by local market traders seek to reverse this. Developing value markets to link smallholders to profitable outlet and market information are particularly important for trading all products produced by smallholder farmers, including the high-volume value grain and pulse crops, vegetables and meat products (Ferris et al. 2014, Sennuga, 2019). Linking smallholder farmers to markets can help drive sustainable productivity and profits, improve livelihoods and increase household incomes. Furthermore, market access by smallholder farmers is generally considered a critical part of long-term development strategies to reduce poverty and hunger in rural communities in SSA. There are several other factors affecting market access and performance amongst smallholder farmers. Studies by Barreties (2008) and Chapoto et al. (2013) outlined key factors including, location; farm size; financial and linkages to financial services; ability to manage water resources; costs of inputs; transaction costs; price volatility; access to and adoption of production technologies and the use of ICT. Many farmers now have access to mobile technologies (Mugwisi et al. 2015) and smallholders are using this technology to communicate with extension workers, traders, colleagues, and to learn about technology and market opportunities (Fu and Akter 2016).

A key failure point of traditional extension models is the number of farmers per extension officer - they cannot visit all the smallholder farmers effectively and in a timely manner. The ratio in Nigeria is currently 1 extension worker: 3000 farmers (Fawole and Olajide 2012, Ogbe 2016). This ratio of extension worker to farmers is grossly inadequate and highly disturbing considering the World Bank's standard which is 1:500 (Word Bank 2010). Where extension workers act as bridges between researchers and farmers, for example, in traditional $\mathrm{T} \& \mathrm{~V}$ extension the 
ratio should be 1:200 farmers within a cluster so that they can have a meaningful impact by effectively teaching and monitoring the farmers' progress; furthermore, by focusing on lead farmers backed up by farmer to farmer extension, then a ratio of 1: 500 advocated by the World Bank could be effective (Sennuga, 2019).

Key challenges facing extension workers include: extremely low extension agent to-farmers ratios; a lack of essential technical and communication skills for efficient functioning; a lack of a definite plan of work; too few qualified and trained extension staff using outdated information; under resourced transport and logistics; poor, weak and deteriorated infrastructure; extension organization and management problems; unclear extension mandates; lack of job descriptions for staff; poor remuneration of the personnel; and a high rate of absenteeism among staff (see Anandajayasekeram et al. 2008; Chowa et al. 2013, Baig and Aldosari 2013, Sennuga, 2019). Consequently, in a reaction to the worrisome performance in the agricultural sector, the Nigerian Government has embarked on several agricultural interventions and reforms, with policies and programs explicitly designed at reinvigorating the sector to its enviable position in the Nigerian economy between 1959 and 2003.

The use of ICT potentially allows extension workers to contact more farmers with appropriate and up-to-date information in a timely manner. Asenso-Okyere and Ayalew-Mekonnen (2012) stressed that ICT, particularly radio, can enable extension worker to reach about half a million smallholder farmers simultaneously in their local language with knowledge and information which enables farmers, strengthens them, assists smallholders in problem solving and allows farmers to make informed decisions (Oladele 2015). Therefore, the main objective of this study is to identify the factors influencing the effectiveness of traditional extension models among rural dwellers in SubSaharan African communities.

The specific objectives of this study are to:

1. examine the socio-economic characteristics of the rural dwellers in the study area;

2. investigate how effective was traditional extension services delivery in the region;

3. highlight the factors influencing the effectiveness of traditional extension model;

4. ascertain the effect of extension contacts and experience among the rural dwellers;

5. Identify factors that hinder effective communication and contact with extension workers.

\section{Methodology:-}

\section{Kaduna State of Nigeria as the study area:}

This study was conducted in two randomly selected Local Government Areas of Kaduna State, Northern Guinea Savannah ecological zone of Nigeria, West Africa. Kaduna State is located between latitudes $9^{0} 03^{1}$ and $11^{0} 32^{1}$ North of the equator and longitude $6^{0} 05^{1}$ and $8^{0} 38^{1}$ East of the Greenwich Meridian (Kaduna State Ministry of Agriculture 2014). However, two rural communities (Bassawa and Shika) were purposefully due to active engagement of the rural farmers in agricultural production in the district and for its proximity to Ahmadu Bello University, Zaria to facilitate access for the researcher and his assistants.

\section{Economic Activities:}

The major economic activity conducted by the rural dwellers in the two communities is farming. Very few people engage in hunting and small scale business. The major food crops grown are yam, maize, millet, groundnut, rice, beans, melon, sweet potato, cassava, guinea corn and vegetables such as pepper, tomato and carrot.

\section{Population of the study and Research design:}

The study involved rural farmers in the two communities including those who had access to agricultural extension workers and those who are not. The study employed case study research design in order to explore and obtain indepth information related the effectiveness of traditional extension models among rural dwellers in Sub-Saharan African communities and extension workers in their real-life settings.

\section{Sample Size and Sampling Techniques:}

Purposively sampling techniques was employed to selecte the sample size for the study. Two rural communities (Bassawa and Shika) were purposely selected out of 18 villages/communities primarily on the basis of their age-long agricultural practice and presence of adoption practices noted there. Moreover, Bassawa community benefited in the Adopted Village Concept project initiated by NAERLS, ABU, Zaria in 2012, while Shika community did not (Sennuga, 2019). Conversely, the two communities are the same in every respect except that one (Bassawa) is an adopted village from NAERLS. The two communities are similar in agro-climatic, ethnic group, religion and 
cultural settings. There is no climatic or agronomic difference between these communities; they are just 300 metres apart. However, one is an Adopted Village by the National Agricultural Extension and Research Liaison Services (NAERLS) ABU, Zaria and the other is not. The Shika community gets only public extension services with about 3000 farm families per extension agent while Bassawa community receives extension services plus the research education establishment from Adopted Village Program with estimated ratio 1:85 farm families (filed survey, 2016).

\section{Sample size:}

The sample size for the study was 200 smallholder farmers. It consists of 100 farmers from each community. In addition, Extension agents were purposively selected -5 agents each from 4 institutions that provide extension and advisory services in the country namely; the government (ADPs), Non-Governmental Organization (NGO), Academia and the Private sector. A total number of 20 extension agents.

\section{Participants and Data Collection:}

Within each community, smallholder farmers were invited to participate in the study through village/community meetings, in which 137 attended from Bassawa and 143 from Shika, and 8 agricultural extension workers were in attendance. From each community, 100 farming households were randomly selected giving a total of 200 smallholder farmers; primarily on the basis of volunteer families and the list of farmers provided by the extension workers (Government KADP office) working with the farmers in the study area. The other criteria for individual participants were as follows: age between 18 and 65 years, farming experience, interested in participating, and permanent resident in the community. The foremost rationale for selecting 100 farmers per community were based largely on the number of farming households that volunteered and showed interest during the community meetings, as well as conformed to the previously mentioned criteria.

Similarly, five (5) extension workers each from 4 institutions that provide extension and advisory services in the country namely; the government (ADPs), Non-Governmental Organization (NGO), Academia and the Private sector. A total number of 20 extension workers participated in the focus group discussions and in-depth interviews at Ahmadu Bello University.

\section{Data collection:}

The study made use of both qualitative and quantitative methods. It was projected that the combination of the two methods would complement each other to ensure excellent results. Primary data were collected using structured questionnaires, focus group discussion and in-depth interview from both rural dwellers and extension workers. Secondary data which relate to the objectives of the study were collected from the office Kaduna State Agricultural Development Project (ADP) and National Agricultural Extension and Research Liaison Services (NAERLS), ABU, Zaria.

\section{Data analysis:}

The data collected were analyzed using the Statistical Package for Social Sciences (SPSS) version 24 from which various statistical computations (such as charts, percentage, spearman correlation and rank) were done.

\section{Findings And Discussions:- Respondents' Socio-economic Characteristics:}

Age :

The age of the farmers in households ranged from 20 to 70 years. 59.2\% of them fell within the middle age of 31 50years in both communities. This suggests that the majority of the respondents were within their economic active age and this enhances their productivity in order to be food secure (Figure 1). The old age group (51-70) had the lowest impact in farm work with $24.2 \%$ contributing to active farming among the sampled population and the age group looks similar in both communities. However, it is generally assumed that younger people tended to be more productive than their older counterparts. Although, there are some variance in the figures (between the communities), the finding of the chi-square analysis revealed that there was no statistically significant difference between the two communities. 


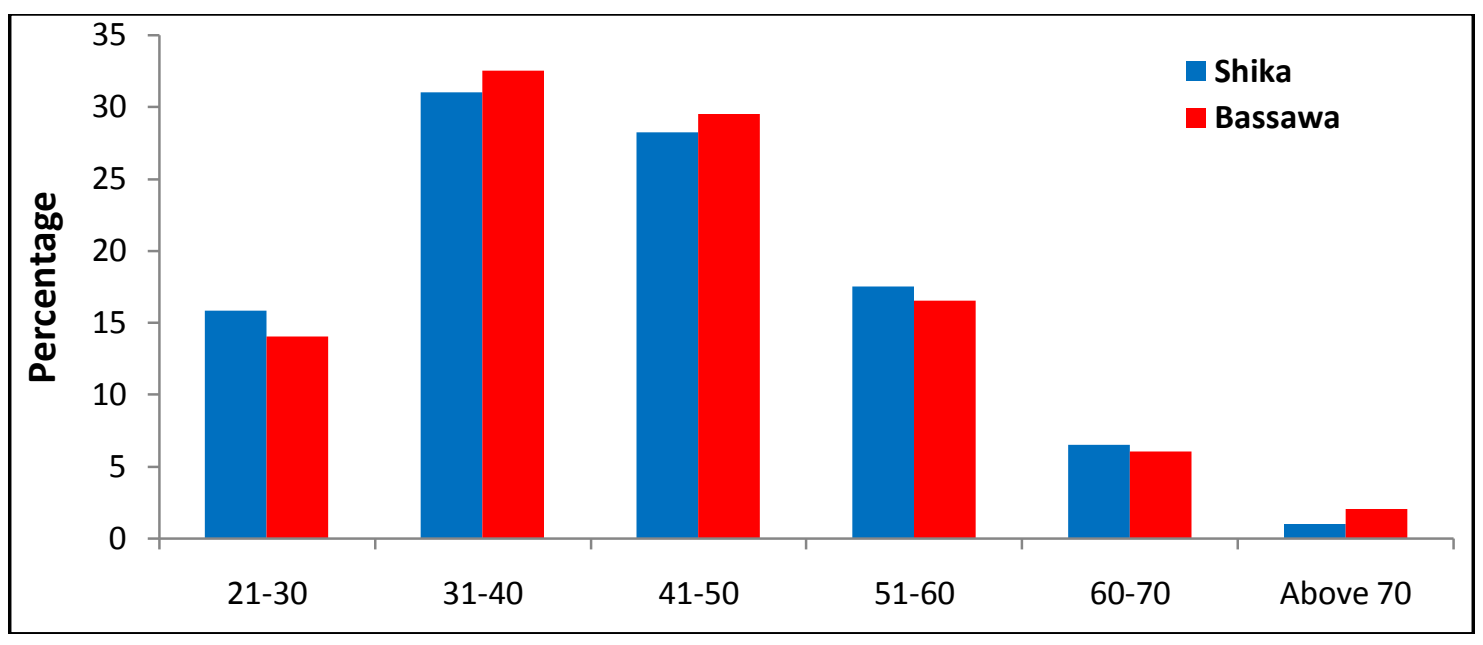

Figure 1:- Age distribution of the respondents. Scale: \% Source: Survey; Shika $n=100$, Bassawa $n=100$

\section{Education Level of Respondents:}

The results shows that, $40 \%$ and $37 \%$ of the respondents had acquired primary education in Shika and Bassawa respectively, while $14 \%$ and $10 \%$ had secondary education in both communities. Only $6 \%$ and $4 \%$ of the respondents possessed higher education (Figure2); however, a chi-square test shows that there was no statistically significant difference between the farmer's educational levels of the two communities.

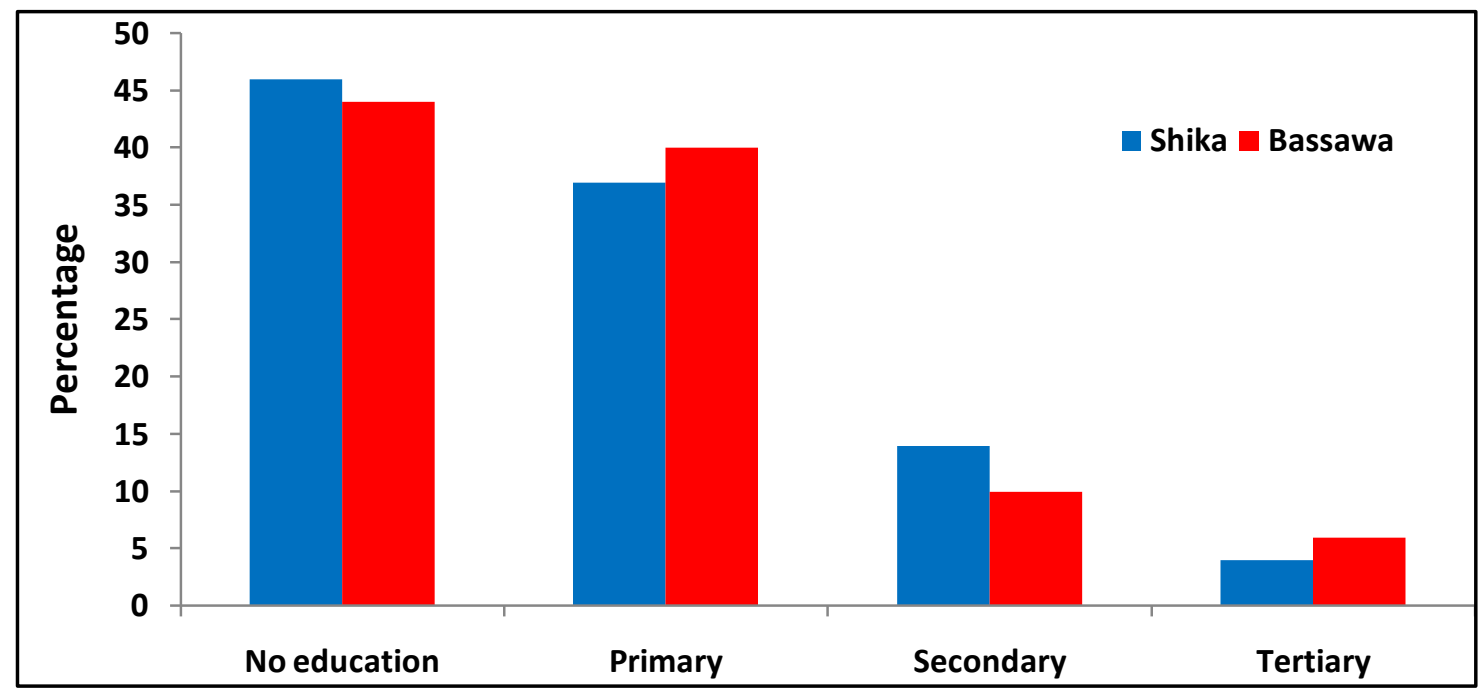

Figure 2:- Distribution of the respondents by educational status

Source: Survey; Shika $n=100$, Bassawa $n=100$

\section{Household Size:}

Household sizes reveal that the dominant class range is 1-10 persons and represents half of the households; this is followed by 11-20 persons in the family representing over a third of households. Farmers in both communities have fairly large household sizes (Figure 3). The result is not surprising because large family sizes are the norm in the Northern part of Nigeria and large families provide accessible workforces. Also the cultural tradition allows the men to marry at most four wives. The finding of the chi-square analysis shows that there was no significant difference between the household sizes of the two communities. 


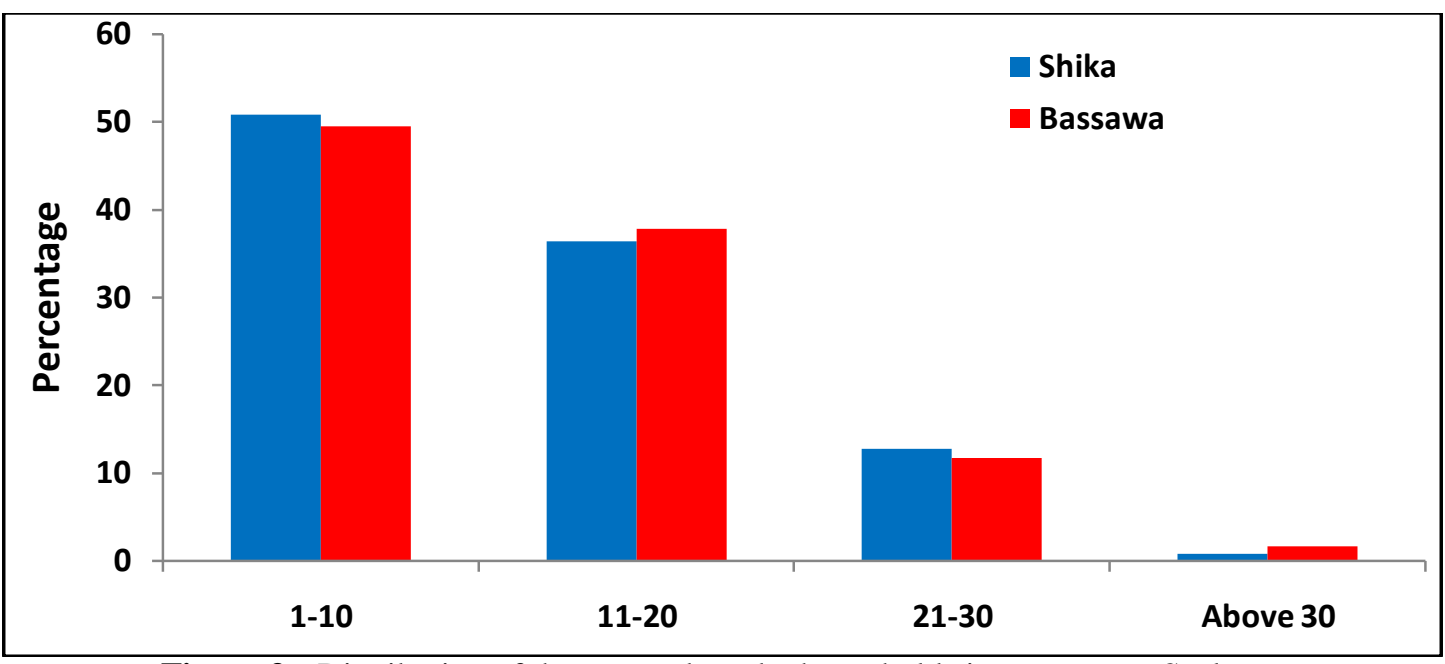

Figure 3:- Distribution of the respondents by household size

Source: Survey; Shika n=100, Bassawa $n=100$

\section{Farm Size:}

$59.2 \%$ of the participants from Shika have a farmland holding of less than 2 hectares compared to $61 \%$ of the farmers from Bassawa (Figure 4). The mean size of farm was 2.65 and 2.48 hectares for Shika and Bassawa respectively. The results show that the vast majority of the respondents in the area were small scale farmers. Chisquare analysis again revealed that there was no significant difference between the farm sizes of the two communities.

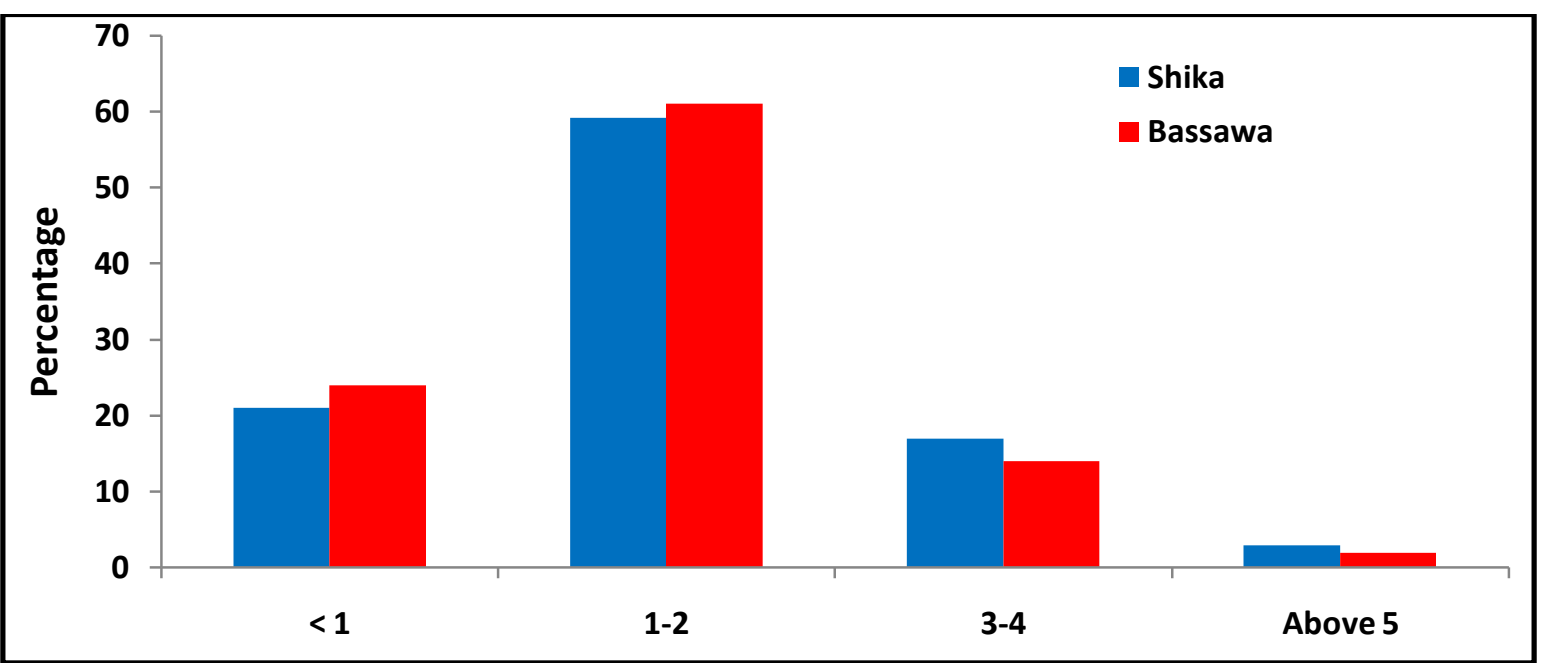

Figure 4:- Distribution of the respondents by farm size in hectare Scale: \%

Source: Survey; Shika $n=100$, Bassawa $n=100$

\section{Household Assets:}

The result shows that $58 \%$ and 54\% of the households from Shika and Bassawa respectively keep chickens (Figure 5). Meanwhile, $46.5 \%$ of the farmers interviewed keep sheep and goats in Bassawa. A sizeable proportion of the respondents $(35 \%)$ from Bassawa also indicated that they rear cattle and only 6\% specified that they keep other livestock such as camel, duck, turkey etc. Also, 7.5\% respondents from Shika also kept similar livestock. The baseline livelihood survey shows that no single household keeps pigs in the study area. This was attributed to the religion of the respondents. The result of the chi-square analysis revealed that there was no statistically significant difference between the two communities. 


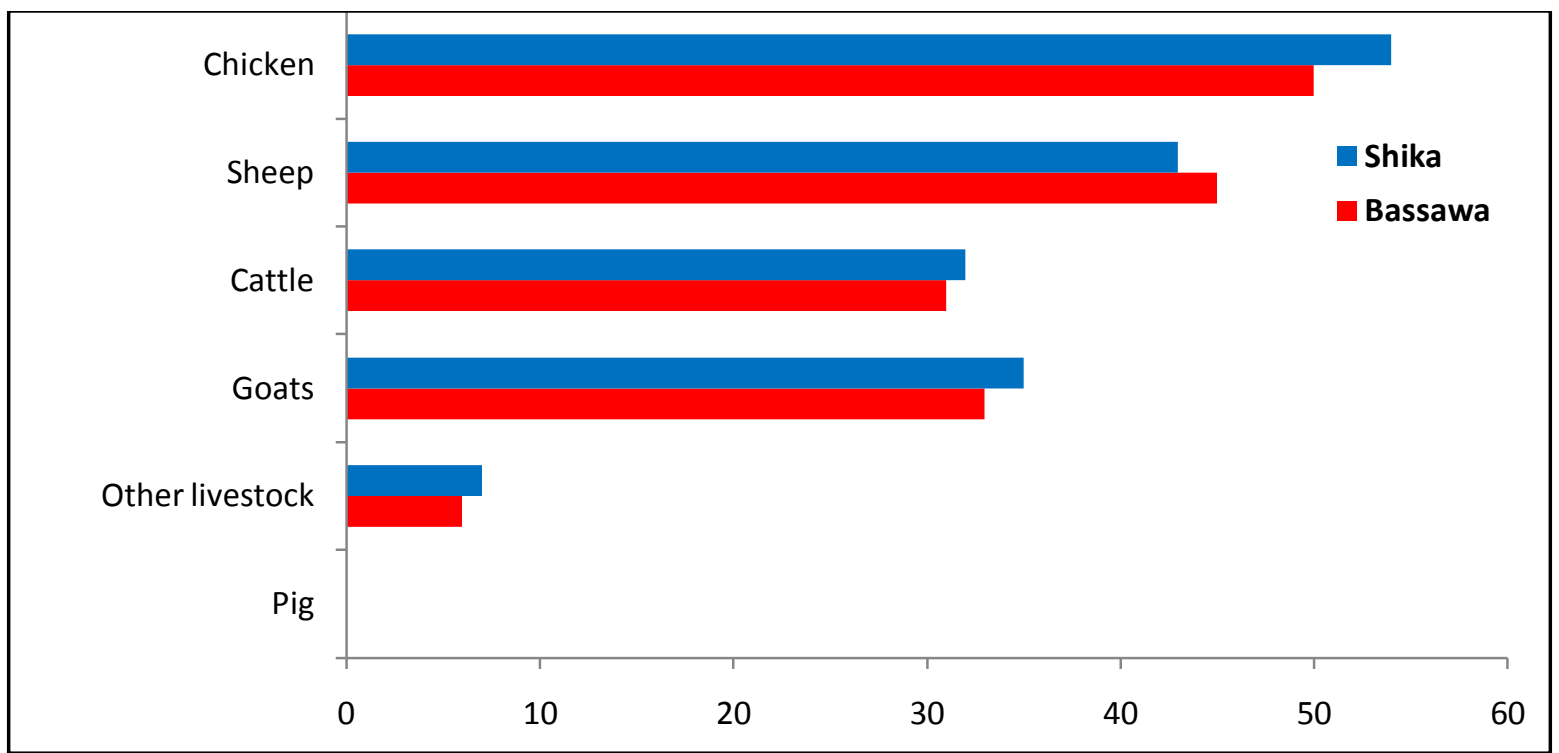

Figure 5:- Distribution of the respondents' main household assets $\quad$ Scale: $\%$

Source: Survey; Shika n=100, Bassawa $n=100$

\section{The Major crops cultivated:}

The study shows the seven major crops cultivated by the households in the study. As illustrated in figure 6 , the findings indicate that maize, millet, cowpea and groundnut were prevalent and dominated the study area with $27.3 \%$, $19.6 \%, 14.7 \%$ and $13.3 \%$ respectively of respondents growing them, while sorghum, tomatoes and onions were also actively cultivated in the area. The chi-square analysis shows that there was no statistical significant difference between the two communities in terms of crops cultivation.

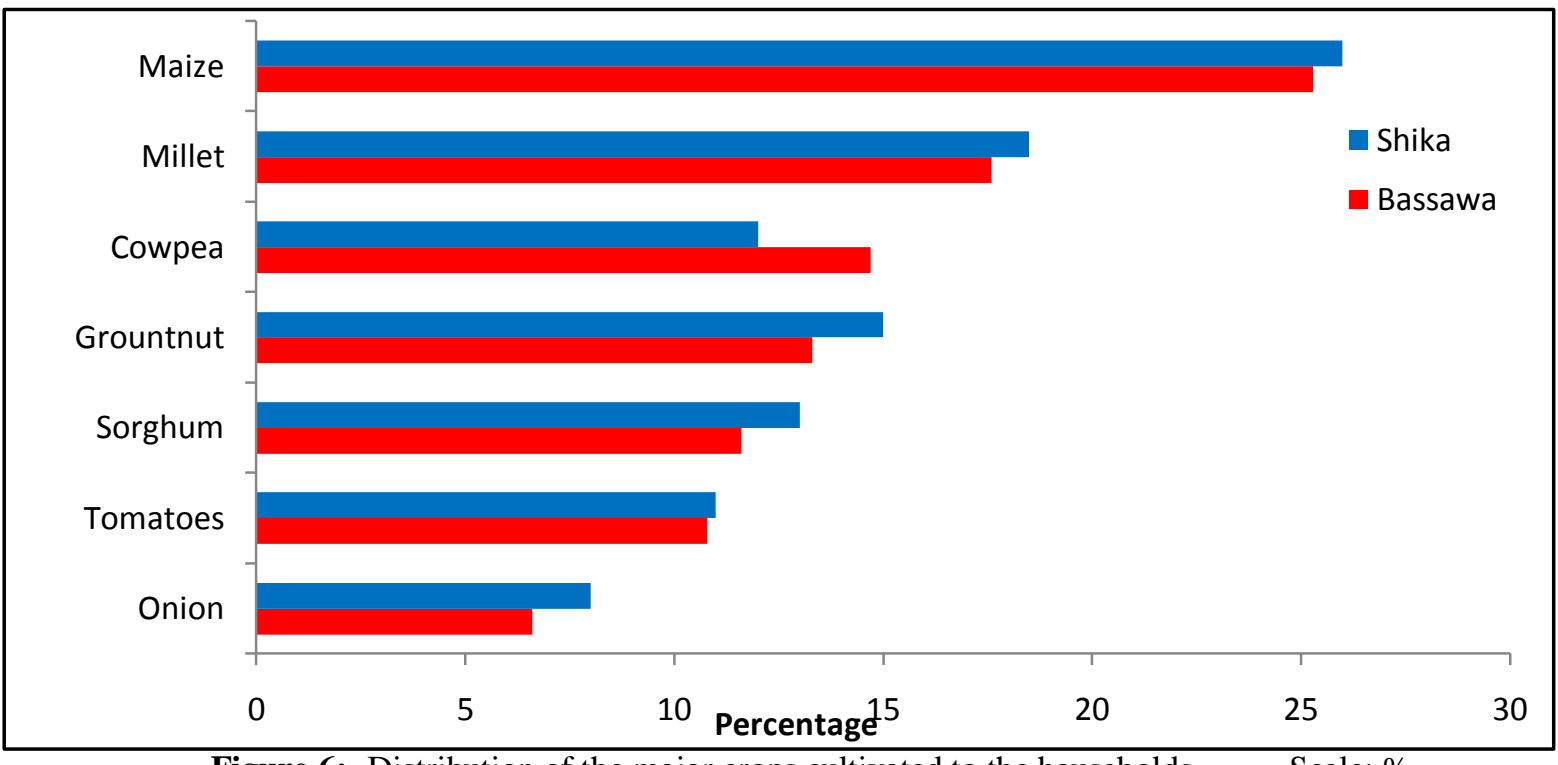

Figure 6:- Distribution of the major crops cultivated to the households $\quad$ Scale: \%

Source: Survey; Shika $n=100$, Bassawa $n=100$

\section{Type of irrigation system used by farmers:}

The findings reveals that $58.3 \%$ of the households interviewed used portable water pumps for their farming operations while $13.3 \%$ and $10 \%$ used sprinkler and bucket techniques respectively during the dry season. However, $12.2 \%$ of the farmers indicated that they do not use irrigation systems for their farming production. The erratic, late onset or early withdrawal of the rainy season in the study area caused frequent crop failures. This suggests that farmers using portable water pumps have the potential to improve their crop productivity and income. 
However, those farmers who do not use any irrigation system during the off season indicated that they alternatively engaged in some petty trading in the communities and its environment during the dry season. Chi-square analysis shows that there was no statistical significant difference between the two communities in terms of cropping.

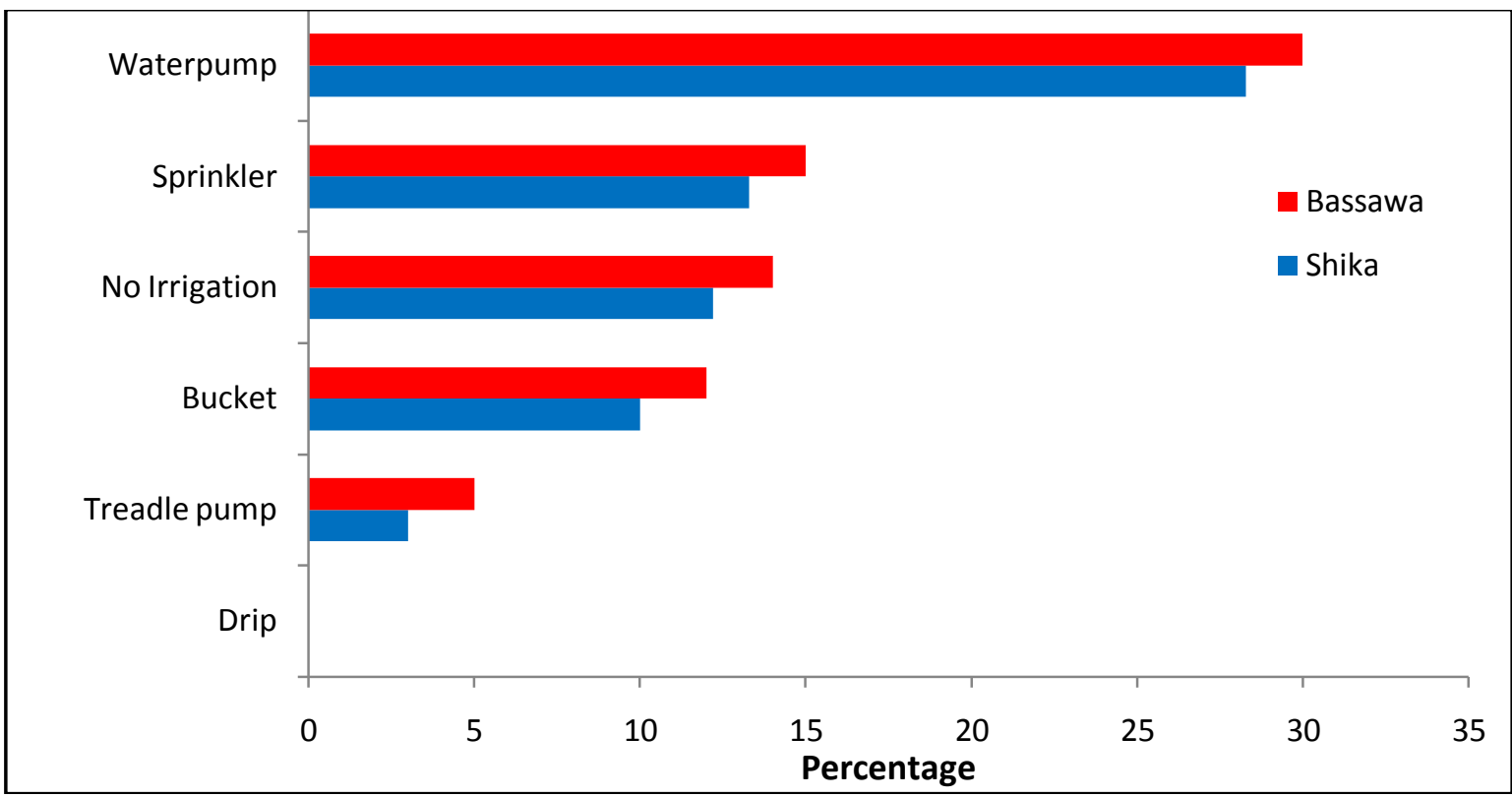

Figure 7:- Distribution of the type of irrigation used by farmers Source: Survey; Shika $n=100$, Bassawa $n=100$

Distribution of the Respondents According to Extension Contact for the Adopted Village (Bassawa) and (Shika):

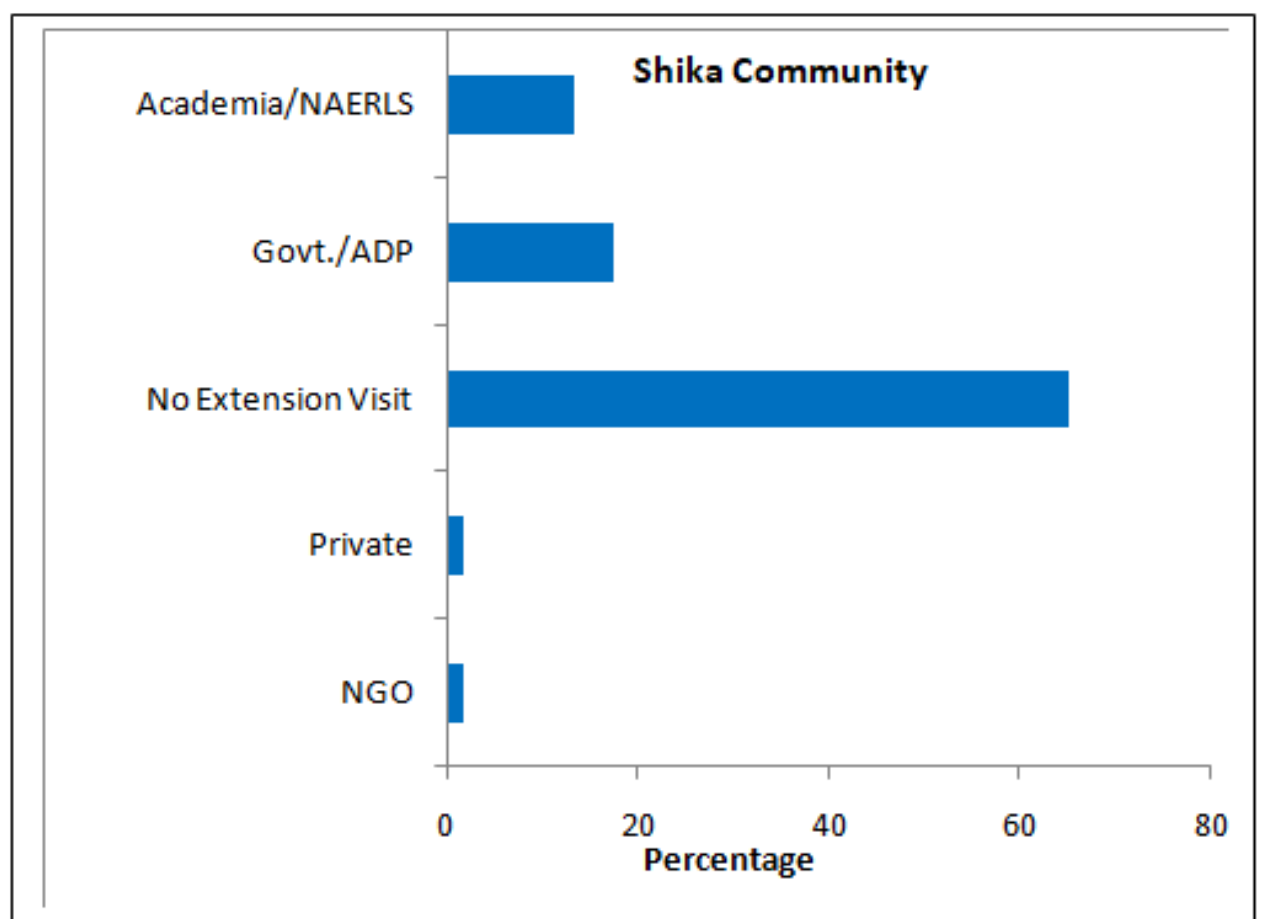

Figure 8a:- Distribution of the respondents according to extension contact for Shika Community (Non-Adopted Village).

Source: Survey; Shika $n=100$

Scale: \% 


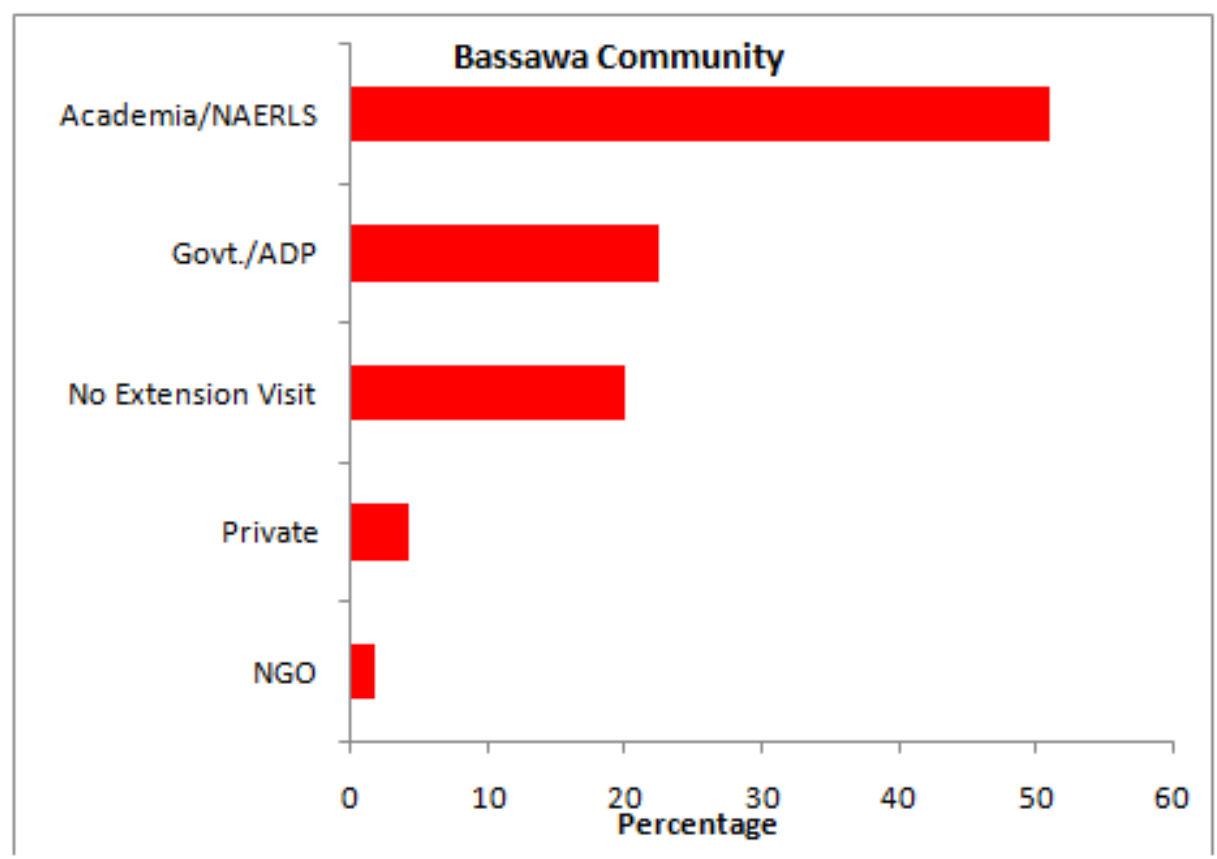

Figure 8b: Distribution of the respondents according to extension contact for Bassawa Community (Adopted Village by NAERLS)

Source: Survey; Bassawa $n=100$

Scale: \%

The Effectiveness of Traditional Extension delivery in the study area:

The survey results showed that the majority $(87 \%)$ of the smallholder (Shika) respondents had negative perceptions of the effectiveness of the extension services in the area (Figure 9). While, 95\% of the respondents from Shika community reported that they had no contact with extension workers in the last one year (Table 1). The chi-square analysis revealed that there is statistically significant difference between Shika and Bassawa communities in terms of extension experience and support. However, although farmers in the Bassawa community had higher levels of contacts with extension workers, it is interesting to note that the majority of farmers in the community still rated extension as ineffective.

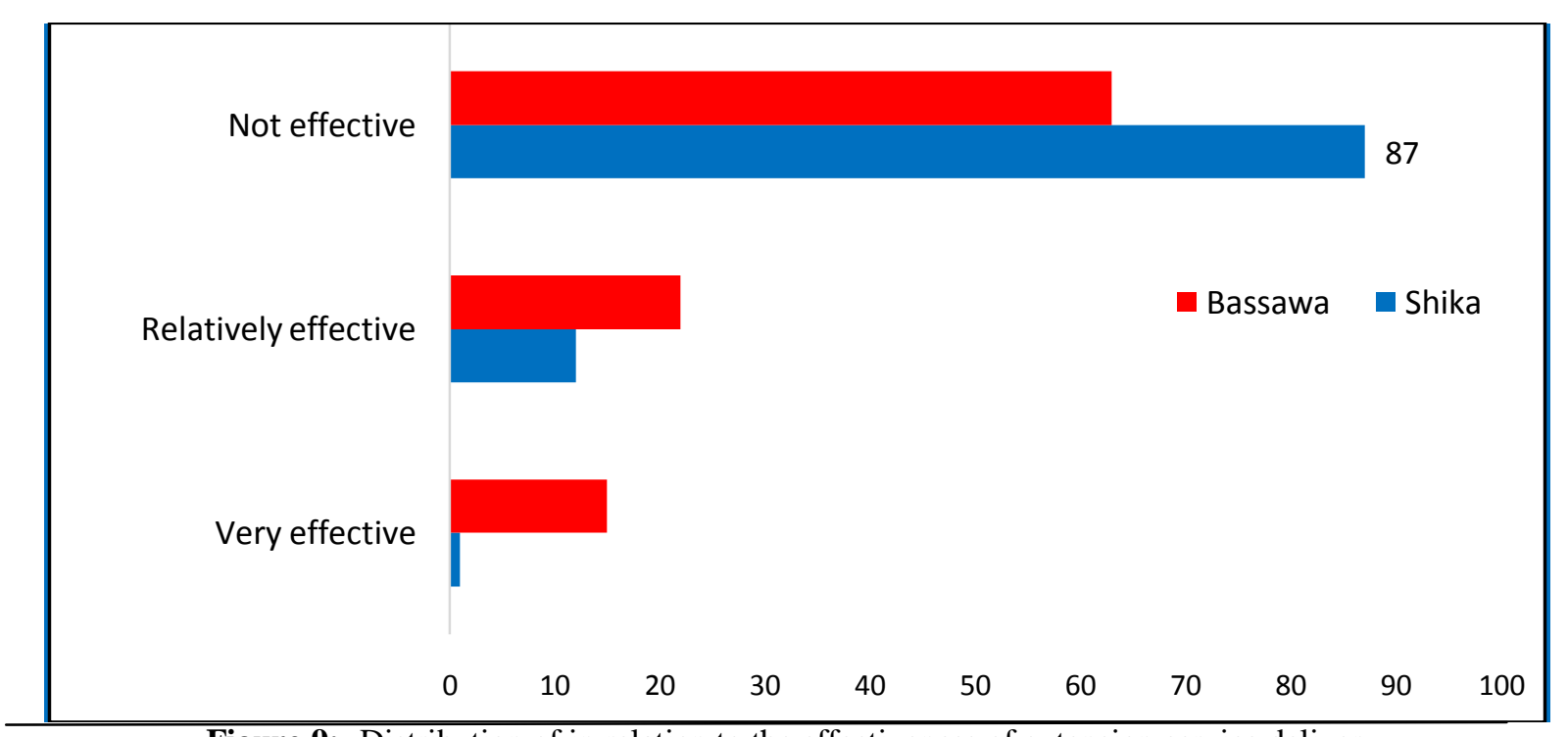

Figure 9:- Distribution of in relation to the effectiveness of extension service delivery. Source: Survey; Shika $n=100$, Bassawa $n=100$

Scale: \% 
Table 1:- Chi-squared analysis Distribution of respondents in relation to the effectiveness of traditional extension models.

\begin{tabular}{|c|c|c|c|c|c|c|c|}
\hline \multicolumn{3}{|c|}{$\begin{array}{l}\text { How effective is extension } \\
\text { services delivery in your area? }\end{array}$} & $\begin{array}{l}\text { Not } \\
\text { effective }\end{array}$ & $\begin{array}{l}\text { Fairly } \\
\text { effective }\end{array}$ & Effective & $\begin{array}{l}\text { Very } \\
\text { effective }\end{array}$ & Total \\
\hline \multirow[t]{2}{*}{ Total } & \multicolumn{2}{|c|}{ Observed count } & 0 & 31 & 49 & 12 & 100 \\
\hline & \multicolumn{2}{|c|}{ Expected count } & 8.0 & 31.0 & 49.0 & 12.0 & 100.0 \\
\hline \multirow{3}{*}{$\begin{array}{l}\text { How effective is } \\
\text { extension services } \\
\text { delivery in your } \\
\text { area? }\end{array}$} & \multicolumn{7}{|c|}{ Chi-square Tests } \\
\hline & Chi-squared & \multicolumn{2}{|l|}{ df } & \multicolumn{2}{|l|}{$\begin{array}{l}\text { Sig. } \\
\text { (p-value) }\end{array}$} & Shika & Bassawa \\
\hline & $93.520^{\mathrm{a}}$ & \multicolumn{2}{|l|}{9} & \multicolumn{2}{|l|}{$0.000 * *$} & $\begin{array}{l}95 \% \\
5\end{array}$ & $\begin{array}{l}28 \% \\
72\end{array}$ \\
\hline
\end{tabular}

Source: Evaluation survey 2016; Shika $\mathrm{n}=100$, Bassawa $\mathrm{n}=100, \mathrm{P}<0.01$ is significant

\section{Factors Influencing the Effectiveness of Traditional Extension Models in Nigeria:}

The extension workers focus group participants were asked to mention the factors influencing the effectiveness of traditional extension service. The respondents (extension workers) gave a number of factors that influence the effectiveness of traditional extension. These factors have been grouped and are reported in Figure 10.

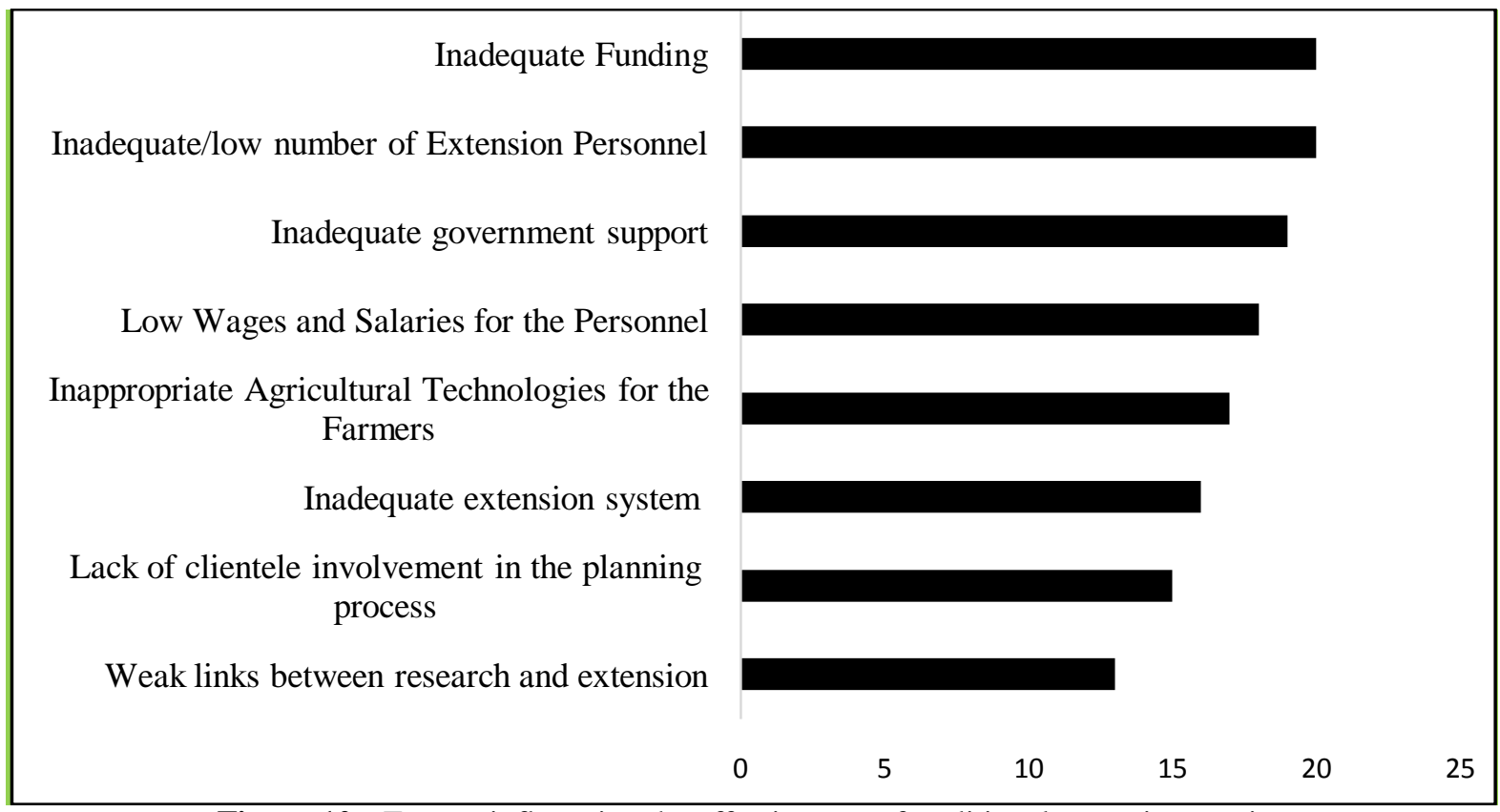

Figure 10:- Factors influencing the effectiveness of traditional extension service

$(\mathrm{n}=20)$ Scale: 20 Extension workers

\section{Inadequate funding:}

Insights gained from the investigation suggest that poor funding is among the numerous challenges facing agricultural extension system in Nigeria. The study further revealed that the main source of funding for extension activities in Nigeria was from the Federal and State government, and the system has been starved after the withdrawal of World Bank assisted funds. Consequently, the sector cannot deliver effectively in the face of this death in funding. The focus group discussion interviews have shown that the funding level of agricultural extension activities in the country has been extremely poor and this has contributed to the inconsistency in extension services and low adoption which brings about low productivity in subsistence farming. Moreover, lack of funding could prevent village extension workers from visiting farmers, in order to conduct farm demonstrations and training to sensitize farmers. The findings from this study are supported by the surveys conducted by Donye et al. (2014) and Imoloame and Olanrewaju (2014) who emphasised that grossly inadequate funding, training and technical advice are the key factors that contribute to the ineffective delivery of services by the extension workers in Nigeria. 


\section{Inadequate/Low Number of Extension Personnel:}

The findings of this study have revealed that there is a need for an increased number of extension officers in order to reach more smallholder farmers. The insight gained from the investigation also revealed that in the study area, the extension worker ratio to farm families is standing at a ratio of one extension worker to 3,000 farmers. This finding clearly suggests that inadequate staffing of extension workers in one of the major constraints to the ineffective extension sector in Nigeria and other developing countries.

\section{Inadequate Government Support :}

Evidence from the current study has shown that the Nigeria agricultural extension services are suffering because of inadequate government support and lack of a consistent approach to the sector. Insight from the investigations revealed that extension workers' and farmers' views concurred that there was a lack of government support to meet the transport cost for visiting farmers in the remote villages. A farmer affirmed that "we hardly receive extension visits and you know we are local people, we need support from the government". This problem has been noted in the literature (Okeke et al. 2015, Akinnagbe and Olaolu 2016) which emphasizes that inadequate government support for extension services and poor government policies and programmes in agriculture are major barriers to the sector.

\section{Low Wages and Salaries for the Personnel:}

The findings from the study have shown that low wages and salaries are among the factors militating against the effectiveness of agricultural extension and advisory services in Nigeria. Like many other civil servants in Nigeria, extension professionals revealed that the wages are not only extremely low, but are not paid when due. They revealed that poor wages are a constant source of frustration. This study identified that due to seven months lack of salaries or unpaid arrears, the majority of the officers effectively engaged themselves in secondary occupations to ameliorate their suffering. Indeed, lack of wages or unpaid salaries is adversely affecting the effectiveness and efficiency of extension service delivery in the study area. The findings of this study are supported by the studies of Ogunremi and Olatunji (2013) and Okwoche et al. (2015) on the determinant of job satisfaction among extension workers and officers, who concluded that poor remuneration, irregular salaries and allowances for the field extension agents and officers are some of the barriers to the effectiveness of agricultural extension in Nigeria.

\section{Insufficient and Inappropriate Agricultural Technologies for Farmers:}

Insights from the study have revealed that inadequate research, limited extension and farmer linkages to assist demand-driven research and enhance the use of best agricultural practices technologies continue to restrain efforts to increase farmers' agricultural productivity. As a result, smallholders continue to use insufficient and inappropriate agricultural technologies which contribute to low agricultural productivity. The findings suggest that there is a need for extension services that can easily facilitate and link research to rural farmers. This result corroborates with the findings from the literature reported in chapter two of the current study. In addition, Fadiji (2013) and Ibrahim (2014) emphasized the provision of relevant and appropriate agricultural technologies that would contribute significantly to the problem of low yields among the smallholder farmers.

\section{Lack of Farmer Involvement in the Planning Process:}

The findings of this study have identified the need for farmers' participation in the planning and technology development processes as mentioned by the extension workers. It was also revealed during the qualitative in-depth interviews that smallholders' decision not to adopt improved technology was a result of a lack of trust in the technology. The research findings suggest that a top-down extension approach is not the best way to disseminate agricultural technology to rural farmers. The findings of this study are supported by the study conducted by Ragasa et al. (2016) who stated that a participatory approach is the best strategy in any technology adoption study target toward smallholder farmers.

\section{Factors that hinder effective communication:}

The findings also revealed that extension workers were constrained by a number of factors that hindered effective communication as identified during the focus group discussions and questionnaire survey. These include: language barriers; poor roads network; excessive distance from the village, farmers' knowledge of ICT; farmers' sources of information, among others (Figure 11). The above-mentioned concerns made it extremely difficult for extensionists to disseminate information and to effectively communicate extension programmes to rural farmers. 


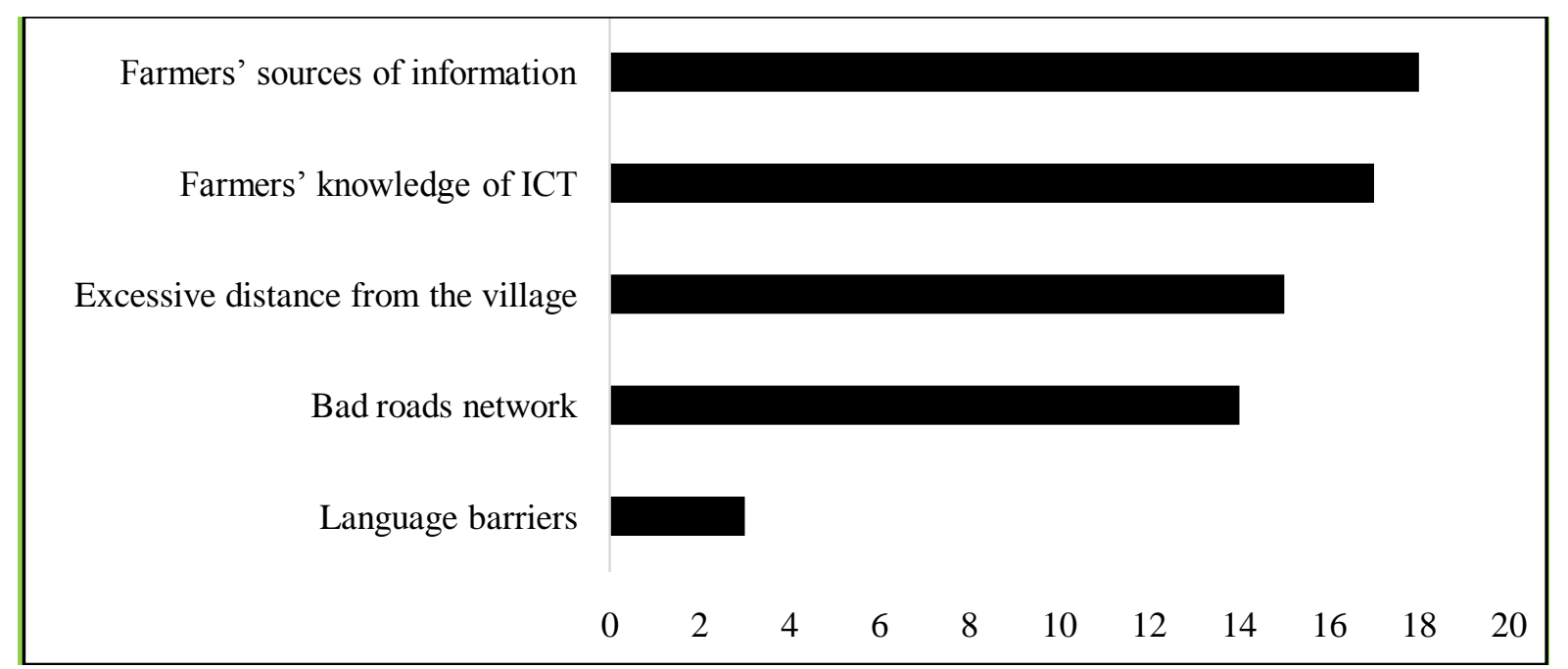

Figure 11:- Factors that hinder effective communication in the study area as cited by extension staff $(\mathrm{N}=20)$ Scale: 20 Extension workers.

The table shows the Spearman rank correlation between various factors that hinder effective communication and contact with extension agents. The Spearman rank correlation is non-parametric which was used to identify and test the strength of the relationship between two set of data that are categorical in nature but drawn from a bivariate normal population (Field 2009). Spearman's correlation works by calculating Pearson's correlation on the ranked values of the data. Ranking (from low to high) was achieved by assigning a rank of 1 to the lowest value, 2 to the next lowest and so on (Wilson, 2016). On whether farmers had contact with extension agents, the extension workers indicated yes or no. The answer was on scale or rank of 1 to 5. Table 2 gives the summary of the estimated results.

Table 2:- Spearman rank correlation between factors that hinder effective communication and contact with extension agents $(\mathrm{N}=20)$.

\begin{tabular}{|l|l|l|l|}
\hline Factors that Hinder Effective Communication & $\begin{array}{l}\text { Contact with } \\
\text { extension agents }\end{array}$ & $\begin{array}{l}\text { Spearman } \\
\text { correlation }\end{array}$ & P-value \\
\hline Language barrier & 2.5 & 0.635 & $0.001 * *$ \\
\hline Bad roads network & 1 & 0.772 & $0.000^{* *}$ \\
\hline Excessive Distance from the villages & 24 & 0.852 & $0.001 * *$ \\
\hline Age of the farmers & 71 & 0.585 & 0.156 \\
\hline Farmers' knowledge of ICT & 0 & 0.376 & 0.174 \\
\hline
\end{tabular}

Source: Evaluation survey 2016; P $<0.05$ is significant

To shed further light on the factors that hinder effective communication to rural farmers as pointed out by the extension workers, survey data provides some useful insights. A correlation was conducted to explore the relationship between the variables and effective communication. As shown in Table 2, the results of the variables reveal that there was a positive and statistically significant relationship between language barriers, bad roads network and excessive distance from the villages with ineffective communication of agricultural information (Table 2). This suggests that language is important for effective communication to take place and has a significant impact. Communication methodologies and tools can help to overcome this language barrier, thus making the work of extension agents more productive and effective. Also, insight from the interviews with the extension workers suggests that a good communication strategy can establish a dialogue with rural farmers by involving them in the planning and development process and by conveying knowledge in a participatory way for improved farming activities.

\section{Frequency of Contact with Extension Agents:}

Figure 12 indicates that the majority $(79.5 \%)$ of the evaluation survey respondents had no contact with extension agents in the last six months from Shika community, while $72 \%$ had no extension contact from Bassawa community. This suggests that after the project in year 2012 Bassawa community had reverted back to no regular contact with 
extension agents. Only $17 \%$ and $24 \%$ of the farmers from Shika and Bassawa respectively were contacted within the last two months, while only $2.5 \%$ of the farmers from Shika reported being visited fortnightly which is the T\&V system of extension's recommendation. The findings of the study indicate farmers' communication with extension agents is extremely poor in the study area. Farmers interviewed also claimed that extension workers did not visit their villages regularly. The most significant themes were:

"We are local people, we do not have access to vital agricultural information that could help us increase to achieve maximum yields increase. We need assistance from the government." (Farmer no 4 - Interview).

"In the past we used to receive extension advice from NARELS, particularly during the adopted village project, however since then hardly can you see extension workers to visit our village communities. We do not really know our transgression". (Farmer no 2 - Interview)

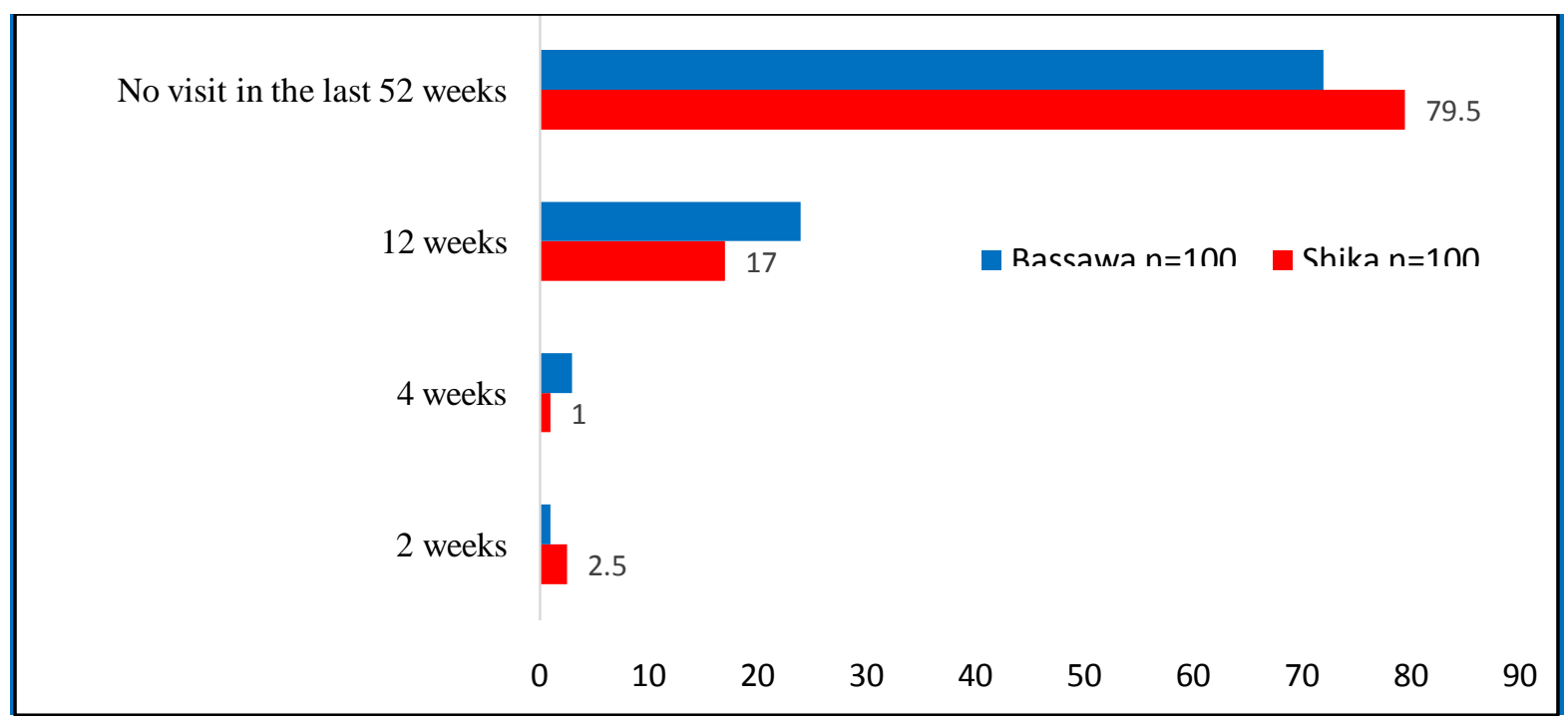

Figure 12:- Distribution of Respondent's Frequency of contact with extension agents.

Source: Survey 2016; Shika $=100$, Bassawa $=100$

Scale: $100 \%$

\section{Conclusion:-}

This paper has argued that the current extension services in the study area are ineffective and inefficient to meet the needs of rural farmers. Almost all the extension worker participants unanimously reported that after the withdrawal of World Bank funding to ADP, the Federal Government of Nigeria finds it extremely difficult to independently fund the extension and advisory services in Nigeria. Also, 69.5\% of the survey farmers indicated that they had no visit/contact with extension agents in the last year, while $86 \%$ reported that extension service delivery was not effective in the area. Exceptionally low numbers of extension workers and poor funding were ranked as the fundamental challenges confronting extension services in the area.

\section{Recommendations:-}

1. The federal and state ministry of Agriculture should recruit more agricultural graduates' youths and train them. More extension workers need to be hired in order to significantly reduce the problem of the extension workers to farm families' ratio which is currently 1:3000 in the Kaduna State.

2. The Government should endeavour to provide additional funding support to ADP for effective extension services delivery to the rural farmers.

3. Regular technical training should be given to village extension agents and government should provide mobility system (vehicles and motorcycle) to be able to reach the rural communities.

4. The government can also improve the quality of extension services by conducting need assessment programme.

5. Village extension agents working in the study area require to be assisted through the provision of field teaching materials and incentives. 
6. The government should support the development of other partners that are involved in extension delivery to rural farmers such as NGOs, private sectors and farmer cooperative societies.

\section{References:-}

1. Aker, J.C. (2011). Dial 'A' for agriculture: a review of information and communication technologies for agricultural extension in developing countries. Agricultural Economics,42 (6), 631-647.

2. Akinnagbe, O.M. \& Olaolu, M.O. (2016). 'Policy issues for improving monitoring and evaluation of agricultural extension programmes in Nigeria', African Evaluation Journal 3(2), 122-134

3. Akintonde, J.O., Akinboye, O.A., Farayola, C.O. \& Akintola, O.S. (2012). Effect of Training and Visit system on Professionalization of Extension Agents in Osun State Agricultural Development Programme of Nigeria, International Journal of Agricultural Resources Innovation \& Technology, 2(1), 37-41

4. Anandajayasekeram P, Puskur R, Sindu, W. \& Hoekstra D. (2008). Concepts and practices in agricultural extension in developing countries: A source book. IFPRI (International Food Policy Research Institute), Washington, DC, USA, and ILRI (International Livestock Research Institute), Nairobi, Kenya. 275 pp

5. Anderson, J.R., Feder, G. \& Ganguly, S. (2006). The rise and fall of training and visit extension: An Asian mini-drama with an African epilogue. Policy Research Working Paper 3928, The World Bank, Washington, DC.

6. Arokoyo, T. (2005). ICTs Application in Agricultural Extension Service Delivery. In: Adedoyin F.S. (Ed) Agricultural Extension in Nigeria.1st edition. Ilorin: AESON, 245-251.

7. Baig, M.B. \& Aldosari, F. (2013). Agricultural Extension in Asia: Constraints and Options for Improvement. Journal of Animal and Plant Sciences 23, 619-632.

8. Barreties, C. (2008). An ordered Tobit model of market participation: Evidence from Kenya and Ethiopia. American Journal of Agricultural Economic, 88(2), 324-337.

9. Chapoto, A., Haggblade, S., Hichaambwa, M., Kabwe, S., Sitko, N. \& Tschirley, D. (2013). Institutional Models for Accelerating Agricultural Commercialization; Evidence from Post-Independence Zambia, 1965 2012. In Agricultural Transformation in a Global History Perspective, ed. E. Hillboom and P. Svensoon. New York: Routledge.

10. Chowa, C., Garforth, C. \& Cardey, S. (2013). Farmer experience of pluralistic agricultural extension, Malawi. Journal of Agricultural Education and Extension, 19(2), 147-166.

11. Davis, K.E. (2008). Extension in Sub-Saharan Africa: Overview and Assessment of Past and Current Models, and Future Prospects, Journal of International Agricultural and Extension Education, 15(3), 15-28.

12. Donye, A.O., Ja'afar-Furo, M.R. and Obinne, C.P.O. (2014). Improving smallholder farming and extension in Nigeria: the Sasakawa Africa fund for extension education strategy, Agriculture and Biology Journal of North America, 4(2), 97-102.

13. Ejembi, E.P., Omoregbee, F.E. \& Ejembi, S.A. (2006). Farmers' Assessment of the Training and Visit Extension System in Central Nigeria: Evidence from BarkinLadi, Plateau State, Journal of Social Sciences 12(3), 207-212.

14. Fadiji, T. (2013). 'Evaluating the impact of agricultural extension programmes in Sub-Saharan Africa: Challenges and prospects', African Evaluation Journal, 1(1), 1-9.

15. Fawole, O.P. \& Olajide, B.R. (2012). Awareness and Use of Information Communication Technologies by Farmers in Oyo State, Nigeria, Journal of Agricultural and Food Information, 13(4), 326-337.

16. Fu, X. \& Aker, S. (2016). The Impact of Mobile Phone Technology on Agricultural Extension Services Delivery: Evidence from India, Journal of Development Studies, 52(11), 1561-1576.

17. Ibrahim, H., Jing, Z., Min Li, \& Qichang, C. (2014). Perception of Farmers on Extension Services in North Western Part of Nigeria: The Case of Farming Households in Kano State. Journal of Service Science and Management, 7, 57-62.

18. Idachaba, F.S. (2000). Desirable and Workable Agricultural Policies for Nigeria. Ibadan University Press, 3-9

19. Ilevbaoje, I.E. (2008). Training and Visit Extension System Flourishes in Nigeria. BeraterInnen News.

20. Imoloame, E.O. \& Olanrewaju, A.O. (2014). Improving agricultural extension services in Moro Local Government Area of Kwara State, Nigeria, Journal of Agricultural Extension and Rural Development, 6(3), 108-114.

21. Kaduna State Ministry of Agriculture (2014). Agriculture Sector Performance Report: Kaduna State Government Ministry of Economic Planning, 2014 Annual Sector performance Report.

22. Kavoi, J.M., Kamau, G.M. \& Mwangi, J.G. (2014). Gender and Group Dynamics in Subsistence Agriculture the Case Study of Kenya, International Journal of Agriculture Extension, 4(1), 11-18. 
23. Mugwisi, T., Mostert, J. \& Ocholla, D.N. (2015). Access to and Utilization of Information and Communication Technologies by Agricultural Researchers and Extension Workers in Zimbabwe, Information Technology for Development, 21(1), 67-84.

24. Musa, Y.N., Aboki, E. \& Audu, I.A. (2013). The Limitations and Implications of Training and Visit (T\&V) Extension System in Nigeria, Journal of Agriculture and Sustainability 4 (1), 67-76.

25. Ogbe (2016). Quarterly Bulletin release by the Nigerian Minister of Agriculture and Rural Development, 2016.

26. Ogungbile, A.O. \& Olukosi, J.O. (2001). An overview of Problems of the Resource-Poor Farmers in Nigerian Agriculture. In Appropriate Agricultural Technologies for Resources-Poor farmers. J. O. Olukosi, Ogungbile and Kalu, B. A. (eds). The Nigerian National Farming Systems Research Network. NAERLS, Zaria. 21-32pp.

27. Ogunremi, J.B. \& Olatunji, S.O. (2013). Perception of Agricultural Extension Agents on the Privatization of Service Delivery towards the Rural Fish Farmers in Ondo State, Nigeria, Resources and Environment, 3(4), 8790.

28. Okeke, M.N., Hyacinth, U, Nwalieji, C. \& Uzuegbunam, O. (2015). Emerging Role of Information Communication Technologies in Extension Service Delivery in Nigeria: A Review. Journal of Agricultural Extension Abstracted by: EBSCO host, Electronic Journals Service, 19(1), 128-141.

29. Okwoche, V.A.O., Eziehe, J.C. \& Agabi, V. (2015). Determinants of Job Satisfaction Among Extension Agents in Benue State Agricultural and Rural Development Authority (Bnarda), Benue State, Nigeria. European Journal of Physical and Agricultural Sciences, 3(2), 38-48.

30. Oladele, O.I. (2015). Features of agricultural extension models and policy in selected sub - Saharan Africa countries. Journal of Agriculture and Environment for International Development, 105(1), 35-44.

31. Ragasa, C., Ulimwengu, J., Randriamamonjy, R. \& Badibanga, T. (2016). Factors Affecting Performance of Agricultural Extension: Evidence from Democratic Republic of Congo, TheJournal of Agricultural Education and Extension, 22(2), 113-143.

32. Sennuga, S.O. (2019). Use of Information and Communication Technologies (ICTs) among Smallholder Farmers and Extension Workers and its Relevance to Sustainable Agricultural Practices in, A Thesis submitted for the degree of Doctor of Philosophy (PhD), Coventry University, United Kingdom.

33. Wilson, J. (2010). Essentials of Business Research: A guide to doing your research project. London. SAGE Publications.

34. Yegbemey, R.N., Yabi, J.A., Heubach, K., Bauer, S. \& Nuppenau, E.A. (2016). Willingness to be informed and to pay for agricultural extension services in times of climate change: the case of maize farming in northern Benin, West Africa, Climate and Development, 6(2), 132-143. 